\title{
The quality of emergency medical services and the number of places of employment
}

\author{
Dorota $\operatorname{Rębak}_{\text {A,B,C,D,E,F,G }}^{1}$ \\ ${ }^{1}$ Faculty of Health Sciences, Jan Kochanowski University in Kielce
}

\begin{abstract}
\section{Introduction}

Paramedics care for and treat people in situations that pose an immediate risk to their health or life. Emergency medical systems and services are faced with increasingly high requirements; therefore, appropriate organization of medical care is essential. The sense of coherence is considered an important variable related to professional functioning. The aim of the present study was subjective opinions of paramedics concerning an impact of the number of places of employment on the quality of services provided in the light of the sense of coherence.

Material and methods

The study involved 336 professionally active paramedics of ambulance emergency teams employed in the randomly chosen medical facilities in Poland. The research was conducted using a diagnostic survey based on two questionnaires, i.e. the orientation to life questionnaire measuring the sense of coherence (SOC-29) and the anonymous questionnaire designed by the author.
\end{abstract}

\section{Results}

In the study group, $61.61 \%$ of respondents were employed in one medical facility, $33.04 \%$ in two and $5.36 \%$ in three or more facilities. There was a statistically significant correlation between the global sense of coherence, comprehensibility, manageability and meaningfulness versus opinions regarding the quality of emergency services related to the number of places of employment. Paramedics working in one medical facility show statistically significantly higher mean levels of the sense of comprehensibility, manageability and meaningfulness as well as the mean global sense of coherence compared to paramedics working in three or more places of employment. The same correlation was observed between the group working in two places and the group working in three or more places.

\section{Conclusions}

According to the paramedics surveyed, working in the health care entities other than the parent one does not adversely affect the quality of emergency services. The sense of coherence is found to be a personality variable differentiating paramedics in terms of the number of employment places.

rapy, which is one component of rehabilitation of patients suffering from cerebral palsy. Main research issues focused on how parents evaluate the role of hippotherapy in the process of comprehensive physiotherapy of a child with cerebral palsy and whether this form of therapy has a beneficial effect on the physical condition of the child. In addition, the research aimed to demonstrate how parents evaluate the availability of hippotherapy and whether it also affects mental sphere of the patient.

\section{Materials and methods}

The study group consisted of participants of rehabilitation stay, which took place in the village of Wycześniak in the Bolimowski Landscape Park. Rehabilitation holiday was organized by the Foundation for Assistance for Youth and Disabled Children called "HEY KONIKU". The study group consisted of 18 people and was diverse in terms of age (from 7 to 31 years) and gender. Children were accompanied by their parents or caregivers who provided answers to the questions in the questionnaire. In the studies the researchers used a questionnaire of their own design, which included questions about the child and his family, and questions about the subjective feelings of the parents or guardians about the conducted hippotherapy. For the research purpose related to this work, the following research techniques were used: a survey and an interview.

Results

The study showed that $88.9 \%$ of respondents regarded hippotherapy as a form of therapy that meets its therapeutic tasks. Only $11.1 \%$ had no opinion on the subject (Chart 1).

Key words: paramedics, quality of medical services, number of places of employment, SOC 


\section{Introduction}

The current directions and programs concerning the development of health care, including the pre-hospital care, set by the World Health Organisation (WHO) $[1,2]$ caused dynamic changes in the entire health care system in Poland, which are also visible in the field of emergency medical services $[3,4]$.

The profession of paramedics is relatively new. In Poland, education of paramedics has been carried out since the 90ties of the XXth century. Initially, only two-year vocational colleges provided this type of education. In 2000, the first enrolment to undergraduate studies took place [5].

Paramedics care for people in situations imposing immediate threat to their life and health. The major responsibilities include efficient and quick provision of safety to people in places of immediate risk to prevent further increases in the number of victims. Paramedics assess health conditions of individuals at sudden health risks and undertake appropriate medical interventions; they transport them to hospitals, talk to them and mentally support them [6].

The emergency systems and services are faced with increasingly high requirements; therefore, appropriate organization of medical care is essential so that the ensuing events do not interfere with normal functioning of emergency services. The number of victims as well as the complexity and variety of injuries are the factors determining whether the ensuing situations do not exceed the capabilities of local public medical emergency services $[7,8]$.

The sense of coherence (SOC) is considered a very important variable related to professional functioning. SOC can modify the relations between the level of stress experienced and its negative effects. The literature findings regarding the above issues demonstrate a positive relationship between the sense of coherence and professional functioning. The higher the sense of coherence, the higher the satisfaction from work and lower workload as well as stress-related consequences perceived $[9,10,11,12]$.

Since medical professions involve the necessity of strict cooperation with patients and efforts to help them, the importance of the components of coherence to achieve good treatment outcomes should be emphasized, i.e. comprehensibility, manageability and meaningfulness [13].

"The sense of coherence is a global orientation of man expressing the extent to which the individual has a constant but dynamic sense of confidence that 1) the stimuli coming from the internal and external environment throughout life are of structured, predictable and explainable nature; 2) the resources are available to manage the difficulties induced by these stimuli; 3 ) the difficulties in question are a challenge worthy of effort and engagement" [14].

\section{Aim}

The aim of the study was subjective assessment of paramedics regarding an impact of the number of employment places on the quality of services provided in the light of the sense of coherence.

\section{Material and methods}

The study encompassed 336 professionally active paramedics of ambulance emergency teams working in the randomly selected medical facilities in Poland. The study design was approved by the Bioethics Committee of the Faculty of Health Sciences, Jan Kochanowski University of Humanities and Sciences in Kielce (no. 22/2010 of 04.06.2010).

The study group included 235 (90.73\%) men and $24(9.27 \%)$ women with college education; 57 $(74.03 \%)$ men and $20(25.97 \%)$ women had 1st degree (undergraduate) higher education. The majority of respondents were graduates of vocational colleges. The difference in the number of women and men was high. The number of female paramedics with a bachelor's degree was higher than the number of those with a college degree.

The largest group consisted of paramedics below the age of 30 years - 174 individuals (51.79\%), including 114 individuals with a college degree and 60 with a bachelor's degree. The remaining age ranges were as follows: $31-40$ years -81 respondents $(31.27 \%)$ with the two-year education and $12(15.58 \%)$ with the three -year education, $41-50$ years - 52 individuals $(20.08 \%)$ with the two-year education and 3 (3.90\%) with the three-year education and above 51 years of age -12 respondents $(4.63 \%)$ with the two-year education and 2 $(2.60 \%)$ with the three year education.

The research tool was a diagnostic survey based on the orientation to life (sense of coherence) questionnaire (SOC-29) and the anonymous questionnaire designed by the author.

The orientation to life questionnaire (SOC-29) by Antonovsky measures the sense of coherence and its three components: comprehensibility, manageability and meaningfulness. It consists of 29 items in three subscales corresponding to three elements of the sense of coherence mentioned above. Respondents assess each item on a 7-point scale. The final score is the sum of all answers according to the key. The Polish version of this questionnaire was shown to have very high reliability Cronbach`s alpha $=0.78[14]$.

The author's questionnaire contained 33 closed or half-open questions regarding various planes of professional activities of paramedics.

The material collected was statistically analysed using Statistical Package for the Social Sciences (SPSS 14)). The following tests were used:

Chi-square - to measure the relationship between qualitative questions,

ANOVA - to analyse the relation between qu- 
alitative questions of three or more categories versus quantitative variables; post-hoc comparisons were made by the Ryan-Einot-Gabriel-Welch F test,

Mann-Whitney test - to check the relationship between dichotomous qualitative questions and estimation questions,

Spearman $r$ correlation - to analyse the relation between estimation questions and quantitative variables.

$\mathrm{P}>0.05$ was considered statistically non-significant, $\mathrm{p}<0.05$ statistically significant and $\mathrm{p}<0.01$ highly statistically significant. The estimation questions were scored as follows - definitely yes -3 , rather yes -2 , rather not -1 and definitely not -0 .

\section{Results}

Education is not a factor differentiating the assessment of the quality of services provided by paramedics according to the number of employment places at $\mathrm{p}=0.799$ and does not affect the number of employment places $-\chi^{2}(2)=0.53 ; p=0.768$.

In the study group, $61.61 \%$ of respondents were employed in one health care facility, $33.04 \%$ in two and $5.36 \%$ in three or more facilities (Table 1 ).

Table 1 . The number of employment places according to education

\begin{tabular}{|c|c|c|c|c|c|c|}
\hline \multirow{3}{*}{$\begin{array}{l}\text { Answers to the question: } \\
\text { How many health care facilities are } \\
\text { you employed in? }\end{array}$} & \multicolumn{4}{|c|}{ Group } & \multicolumn{2}{|c|}{ Total } \\
\hline & \multicolumn{2}{|c|}{ Vocational college } & \multirow[t]{2}{*}{ 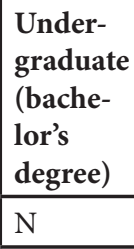 } & \multirow[b]{2}{*}{$\%$} & \multirow[t]{2}{*}{$\mathrm{N}$} & \multirow[t]{2}{*}{$\%$} \\
\hline & $\mathrm{N}$ & $\%$ & & & & \\
\hline In one & 160 & 61.78 & 47 & 61.04 & 207 & 61.61 \\
\hline In two & 84 & 32.43 & 27 & 35.06 & 111 & 33.04 \\
\hline In three or more & 15 & 5.79 & 3 & 3.90 & 18 & 5.36 \\
\hline In total & 259 & 100.00 & 77 & 100.00 & 336 & 100.00 \\
\hline
\end{tabular}

According to the respondents, working in health care entities other than the parent one does not lower the quality of the services provided by them (Table 2).

Table 2. Opinions on impact of working in more than one facility on the quality of services

\begin{tabular}{|l|l|l|l|l|l|l|}
\hline \multirow{2}{*}{$\begin{array}{l}\text { Estimation } \\
\text { questions }\end{array}$} & \multicolumn{2}{|l|}{ Vocational college } & \multicolumn{2}{l|}{ Undergraduate } & U M-W & $\mathrm{p}$ \\
\cline { 2 - 6 } & \multicolumn{1}{|c|}{$\overline{\mathrm{X}}$} & SD & $\overline{\mathrm{X}}$ & $\mathrm{SD}$ & & \\
\hline $\begin{array}{l}\text { Does working } \\
\text { in health care } \\
\text { entities other } \\
\text { than the parent } \\
\text { one (overtime } \\
\text { hours) lower the } \\
\text { quality of servi- } \\
\text { ces provided by } \\
\text { paramedics? }\end{array}$ & 1.21 & 0.92 & 1.34 & 0.91 & 9159.50 & 0.249 \\
\hline
\end{tabular}

Moreover, the relationship between the sense of coheral facilities was analysed and possible negative effects of employment in several places on the quality of services provided was assessed. The findings were presented in tables 3 and 4 . rence and possible employment as paramedics in seve- 
Table 3. The Spearman $r$ correlation coefficient between the sense of coherence and its components versus opinions on lower quality of services provided associated with working in several health facilities

\begin{tabular}{|l|l|l|l|l|}
\hline & comprehensibility & manageability & meaningfulness & $\begin{array}{l}\text { Total sense of cohe- } \\
\text { rence SOC }\end{array}$ \\
\hline $\begin{array}{l}\text { Does working in } \\
\text { health care entities } \\
\text { other than the parent } \\
\text { one (overtime hours) } \\
\text { lower the quality of } \\
\text { services provided by } \\
\text { paramedics? }\end{array}$ & $-0.19^{* *}$ & $-0.22^{* *}$ & $-0.12^{\star}$ & $-0.20^{\star *}$ \\
\hline
\end{tabular}

* - statistically significant $\quad p<0 / 05$

** - highly statistically significant $\quad \mathrm{p}<0.01$.

The findings of analysis demonstrate a statistically significant relationship $\mathrm{p}<0.01$ between the global sense of coherence, comprehensibility, manageability and meaningfulness at $\mathrm{p}<0.05$ and opinions on the quality of services provided according to the number of employment places. The higher the sense of coherence, the stronger the belief that working in several health care facilities does not lower the quality of the services provided by paramedics.
To confirm the above relationship, the mean sense of coherence and its components were analysed in the groups according to the number of employment places. Analysis of variance of intergroup differences was performed; the REGW F test was used for post-hoc comparisons.

The results reveal that the sense of coherence and its components statistically significantly differentiate paramedics according to the number of employment places.

Table 5. Comparison of means of the sense of coherence and its components in the groups differing in the number of employment places and analysis of variance for intergroup differences

\begin{tabular}{|c|c|c|c|c|c|c|c|c|c|}
\hline \multirow{3}{*}{$\begin{array}{l}\text { Dependent } \\
\text { variables }\end{array}$} & \multicolumn{6}{|c|}{ Number of employment places } & \multirow[t]{3}{*}{$\mathrm{F}$} & \multirow[t]{3}{*}{$\mathrm{p}$} & \multirow{3}{*}{$\begin{array}{l}\text { Intergroup differences } \\
\text { (REGW F) }\end{array}$} \\
\hline & \multicolumn{2}{|l|}{$\begin{array}{l}\text { one } \\
1\end{array}$} & \multicolumn{2}{|l|}{$\begin{array}{l}\text { two } \\
2\end{array}$} & \multicolumn{2}{|c|}{$\begin{array}{l}\text { three and more } \\
3\end{array}$} & & & \\
\hline & $\mathrm{x}$ & SD & $\mathrm{x}$ & SD & $\mathrm{x}$ & SD & & & \\
\hline $\begin{array}{l}\text { Comprehen- } \\
\text { sibility }\end{array}$ & 48.70 & 9.62 & 48.37 & 8.53 & 42.89 & 7.40 & 3.33 & 0.037 & $\begin{array}{l}\text { Differences between groups } \\
1 \text { and } 3 ; 2 \text { and } 3\end{array}$ \\
\hline $\begin{array}{l}\text { Manageabi- } \\
\text { lity }\end{array}$ & 51.32 & 8.52 & 49.44 & 8.00 & 45.28 & 7.81 & 5.42 & 0.005 & $\begin{array}{l}\text { Differences between groups } \\
1 \text { and } 3 ; 2 \text { and } 3\end{array}$ \\
\hline $\begin{array}{l}\text { Meaningful- } \\
\text { ness }\end{array}$ & 44.31 & 7.02 & 43.03 & 7.31 & 38.39 & 8.67 & 6.07 & 0.003 & $\begin{array}{l}\text { Differences between groups } \\
1 \text { and } 3 ; 2 \text { and } 3\end{array}$ \\
\hline $\begin{array}{l}\text { Total sense } \\
\text { of coherence } \\
\text { SOC }\end{array}$ & 144.33 & 22.45 & 140.83 & 19.99 & 126.56 & 19.84 & 5.98 & 0.003 & $\begin{array}{l}\text { Differences between groups } \\
1 \text { and } 3 ; 2 \text { and } 3\end{array}$ \\
\hline
\end{tabular}

Analysis of data indicates that there is a relation between the global sense of coherence and its components, i.e. comprehensibility, manageability and meaningfulness, versus the number of places of employment. Paramedics working in one health care facility have statistically significantly higher levels of the sense of comprehensibility (at $\mathrm{p}=0.037$ ), manageability (at $\mathrm{p}=0.005$ ) and meaningfulness as well as the mean global sense of coherence (at $\mathrm{p}=0.003$ ) compared to paramedics working in three and more employment places. The same relation is observed between the group working in two places and the group working in three and more places. 
Figures 1 and 2 present the distribution of the relations mentioned above.

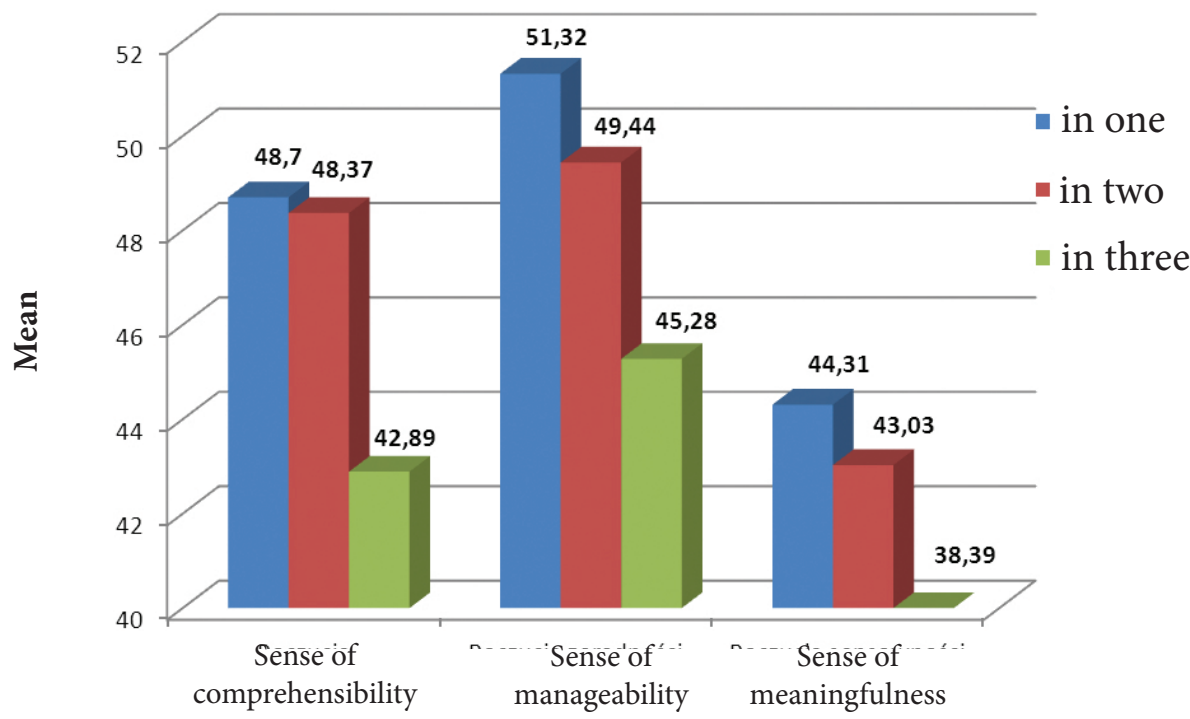

Fig.1. Distribution of the sense of comprehensibility, manageability and meaningfulness in the groups of paramedics according to the number of employment places, comprehensibility, manageability, meaningfulness, in one, in two, in three and more; means.

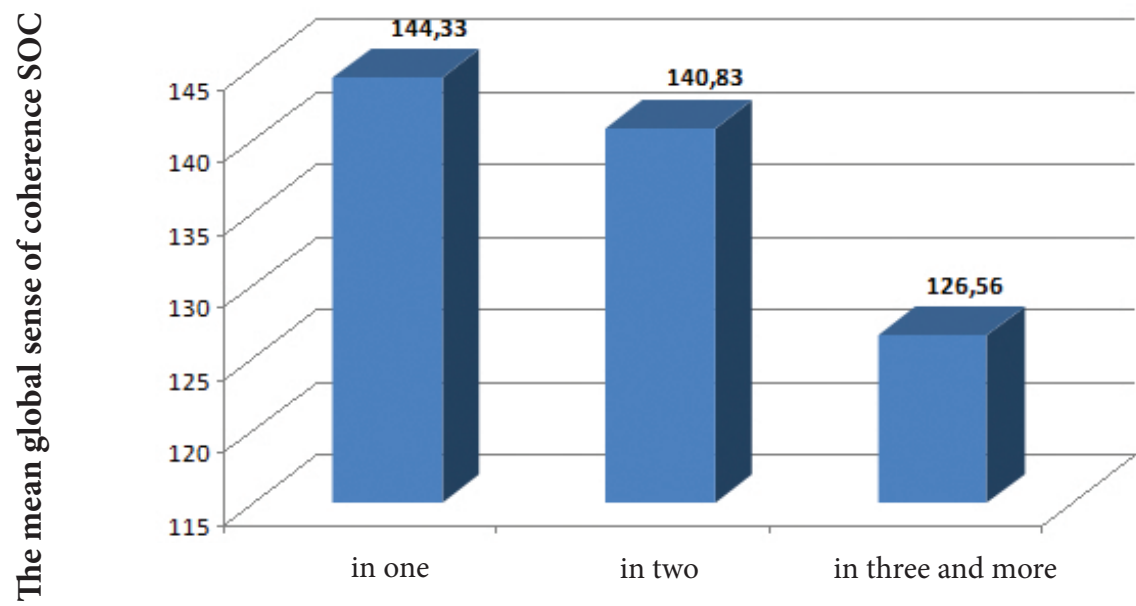

Fig 2. Distribution of the global sense of coherence in groups of paramedics according to the number of employment places

\section{Discussion}

The extent and quality of emergency services require high medical skills and good organisation of medical health care. According to Goniewicz [15], nowadays paramedics are very well educated, which allows them to manage life-threatening conditions, and have good communication and cooperation skills.

Therefore, the only issue of concern is working in several health care facilities. There are two forms of employing paramedics, i.e. an employment agreement and a civil-law agreement. In the latter case, a paramedic has to conduct business activity, i.e. pay monthly insurance fees, taxes, liability insurance, etc. According to Nowak [16], this form of employment requires full commitment and duties in several places, which can be a problem. In some cases, the paramedic is assigned duties simultaneously in two facilities; hence he has to hand the duty over to one of his co-workers or "sell" it to someone on an employment agreement (described in "Głos Szamotulski" and on naszemiasto.pl [17].

In our study, $33.04 \%$ of respondents confirmed working in two facilities while $5.36 \%$ in three or more. According to them, working in more than one health care entity (overtime hours) does not lower the quality of services provided.

Professional activities of paramedics seem to be mentally and physically burdening $[18,19]$, which can 
affect the quality of services provided, especially overtime hours. Our study was to analyse this in relation to the sense of coherence. According to the study findings, the higher the sense of coherence - comprehensibility, manageability and meaningfulness, the stronger the belief that working in several health care facilities does not lower the quality of services provided by paramedics.

The study analysed the mean sense of coherence and its components in the groups differing in the number of employment places. Analysis of variance of intergroup differences demonstrated that the sense of coherence and its components statistically significantly differentiate paramedics as for the number of employment places. Paramedics working in one health care facility had statistically significantly higher mean sense of comprehensibility, manageability, meaningfulness and mean global sense of coherence compared to paramedics working in three or more facilities. The same relationship was found for the group working overtime hours in two places compared to the group working in three or more places.

Physical and mental overburden results in the lack of motivation, helplessness, frustration or even mental and psychosomatic diseases. In medical professions, the above is correlated with the quality of services. According to the Antonovsky concept, a person of strong sense of coherence effectively copes with professional stress, because he perceives the close environment as rational, predictable and understandable and himself as resourceful [14].

The present study revealed higher mean sense of coherence (comprehensibility, manageability, meaningfulness) in the group of paramedics working in one place compared to the remaining respondents; based on the Antonovsky theory, the above finding should indicate better quality of medical services in this group resulting from higher satisfaction from job, less severe perception of work burden and stress-related consequences.

\section{Conclusions}

1. According to respondents, working in several places of employment does not lower the quality of the services provided.

2. The sense of coherence is found to be a personality variable differentiating paramedics as to the number of employment places.

3. The mean scores of sense of coherence in the groups of paramedics differing in the number of employment places demonstrate better quality of medical services provided by paramedics working in one health care facility.

\section{References:}

1. Kobusingye O.C., Hyder A.A., Bishai D., Hicks E.R., Mock C., Joshipura M. Emergency medical system in low-and middle-income countries: recommendations for action. Bull World Health Organ. 2005; 83(8): 626-631

2. The World Health Report 2008, Primary Care, Now More Than Ever. WHO 2008

3. Kuszewski K., Gericke Ch. Health Systems in Transition. Poland; European Observatory of Health System and Policies: 2005; (7)5.

4. Smith J., Haile-Mariam T. Priorities in Global Emergency Medicine Development, Emerg. Med. Clin. North. Am. 2005 Feb; 23(1): 11-29.

5. Gałązkowski R., Paciorek P. Ratownik medyczny w Polsce - aktualna sytuacja prawna W: Konieczny J. red., Ratownik medyczny - problemy edukacyjne i organizacyjno -prawne. Inowrocław - Poznań; Oficyna Wydawnicza Garmond: 2006, s. 15-22.

6. Ustawa $\mathrm{z}$ dnia 8 września 2006 r. o Państwowym Ratownictwie Medycznym [Dz. U. z 2006 r. Nr 191, poz. 1410]

7. $\quad$ Briggs S.M., Brinsfield K. H., Zawadzki A. red. Wczesne postępowanie medyczne w katastrofach. Podręcznik dla ratowników medycznych. Warszawa; Wydawnictwo Lekarskie PZWL: 2007, s.3.

8. Jakubaszko J. Kwalifikowana pierwsza pomoc. W: Biblioteka Polskiego Towarzystwa Medycyny Ratunkowej, Wrocław; 2005, s. 5.

9. Andruszkiewicz A., Basińska M.A., Kubica A. Czynniki wpływające na poziom motywacji do zaprzestania paleniu tytoniu w grupie osób uzależnionych od nikotyny. Folia Cardiologica Excerpta 2010; 5(2): 49-53. 10. Poździoch S., Guły P. Ustawa o Państwowym Ratownictwie Medycznym. Komentarz. Warszawa; ABC a Wolters Kluwer business: 2008; 77.

11. Urbańska B., Kurowska K. Poczucie koherencji (SOC) a zachowania zdrowotne u pielęgniarek. Pielęgniarstwo Chirurgiczne i Angiologiczne. 2010; 3: 90-95. 12. Włodarczyk P. Poczucie koherencji a zachowania zdrowotne. Gdańsk; Lider; 1998, s.13-18.

13. Rongińska T. Diagnostyka źródłem stresu i wypalenia zawodowego w pracy pielęgniarki Uniwersytet Zielonogórski. www.pip.gov.pl/prewencje/stres/doc 14. Antonovsky A. Rozwikłanie tajemnicy zdrowia. Jak radzić sobie ze stresem

i nie zachorować. Warszawa; Instytut Psychiatrii i Neurologii: 2005,s. 34-144.

15. Goniewicz M. Ratownik medyczny - kluczowy zawód systemu państwowe ratownictwo medyczne. W: Konieczny J.(red.) Ratownictwo w Polsce. Lata 19902010. Poznań; Garmond Oficyna Wydawnicza: 2010, s.145-157.

16. http://www.ratowniczy.net/sprzedawanie-i -kupowanie-dyzurow-przez-ratownikow/ [cytowano 01.03.2014]

17. http://oborniki.naszemiasto.pl/arty- 
kul/367580,oborniki-ratownicy-medyczni-handlowali -swoimi-dyzurami,id,t.html [cytowano 01.03.2014]

18. Kowalczuk K., Jankowiak B., Krajewska-Kułak E., Sierakowska M., Lewko J., Krajewska K., Ostapowicz -Van Damme K. Exposure of medical rescuers to aggression at the workplace Ann. Acad. Med. Stetin. 2009; 55(3):76-80.

19. Kowalczuk K., Krajewska-Kułak E., Klimaszewska K., Kondzior D. Wpływ obciążenia psychicznego pracowników zintegrowanego zespołu medycznego na zadowolenie z wykonywanej pracy. Problemy Pielęgniarstwa 2009; 17: 315-320.

Correspondence address:

Dorota Rębak

Department of Health Sciences,

Jan Kochanowski University in Kielce.

Al. IX Wieków Kielc 19

25-317 Kielce

e-mail: dorotar@ujk.edu.pl 